\title{
Algaravia em torno de um desastre
}

\author{
Carlos A. Ferreira Martins*
}

*Carlos A. Ferreira Martins é Professor Titular e ex-Diretor do Instituto de Arquitetura e Urbanismo da USP.
Convite da editoria da Risco para inaugurar este espaço surgiu a propósito de uma pequena coluna para um jornal local de São Carlos que comentava, nos limites de espaço e público, que as manifestações de trabalhadores do $1^{\circ}$ de Maio haviam sido obscurecidas pela notícia de um incêndio que consumiu em poucas horas um edifício ocupado por um movimento de moradia na área central da capital paulista.

Como sempre ocorre nesses casos, distintas narrativas prontamente se apresentaram, boa parte delas mais para comover do que para informar a chamada opinião pública.

Na grande mídia prevaleceu a narrativa da tragédia que, como é habitual, se estruturou em torno de heróis e vilões, deixando as vítimas relegadas ao purgatório de um espaço cinzento, desumanizado como suas vidas cotidianas.

Os heróis foram, como usual, os bombeiros e algum cidadão capaz de colocar a solidariedade acima de sua própria segurança. Como ficamos sabendo aos poucos, neste caso, tratou-se de um jovem chefe de uma equipe de "chapas" da zona cerealista, conhecido por Tatuagem, que depois de salvar quatro crianças do incêndio acabou por sucumbir soterrado no instante em que estava por ser, ele próprio, resgatado.

O heroísmo do jovem e os depoimentos de seus colegas de trabalho criaram um certo ruído para a caracterização generalizante dos ocupantes como "vagabundos".

Os vilões, para a grande imprensa e alguns políticos oportunistas de plantão, foram, também como de hábito, as próprias vítimas. Além da desqualificação dos moradores, jogou-se a culpa no MTST e em Boulos embora nem este movimento nem sua liderança tivessem qualquer papel naquela ocupação em particular. 
O ex e ausente prefeito da Capital, agora em plena campanha para levar seu peculiar estilo de gestão para o governo do Estado, jogou a culpa nos pobres, aqueles que insistem em sujar sua fantasia midiática da cidade linda.

Menos possibilidade de manifestação teve o impopular presidente da república, que viu sua tentativa de ganhar alguns minutos de televisão desaparecerem debaixo de uma saraivada de pedras e objetos vários que o escorraçou do local.

A grande mídia, um pouco mais sutil, não deixou de responsabilizar as vítimas. Consultando os indefectíveis "especialistas", a narrativa titubeante apontava a responsabilidade do incêndio nos materiais e divisórias empregadas para transformar um edifício de escritórios em precária moradia e a rápida implosão do edifício na suposta estrutura metálica do edifício. Gambiarras elétricas ou inseguros bujões de gás também povoaram as longas falas destinadas a manter a atenção do público enquanto o duro trabalho de rescaldo não atingia algum clímax no encontro de corpos soterrados ou, se possível e de maior efeito catártico, no eventual resgate com vida de algum desaparecido.

Quase nenhuma atenção se deu à notícia de que os bombeiros tiveram que trabalhar exclusivamente com a água dos carros pipa porque os hidrantes do local, em plena área central da cidade, não estavam operacionais.

Fora da grande mídia, nas redes sociais e nos sites próprios das entidades e da categoria profissional, arquitetos e urbanistas também se dividiram em narrativas conflitivas. Ou que pelo menos assim foram lidas pelos próprios.

Ficamos sabendo que o edifício em questão, denominado Wilton Paes de Almeida, foi projetado no início da década de 60 pelo arquiteto Roger Zmekhol e inaugurado em 1968 para abrigar os escritórios do conglomerado de empresas Paes de Almeida. Algumas manifestações de arquitetos ou entidades ligadas à preservação enfatizaram a importância histórica e cultural do edifício de 24 andares, que seria um dos mais valiosos exemplares da arquitetura miesiana da capital, com seu apuro tecnológico e característico curtain wall, a ponto de ser tombado em 1992 pelo Compresp, o órgão de patrimônio cultural e arquitetônico do município de São Paulo.

Antes disso, o edifício havia sido repassado, por dívidas tributárias, à propriedade da União, tendo abrigado o INSS e a Polícia Federal entre a década de 80 e 2003, quando foi abandonado e posteriormente ocupado por um dos vários movimentos de moradia da capital, o Movimento de Luta por Moradia Digna (LMD), ligado ao Movimento de Luta Social por Moradia (MLSM).

A grande mídia já havia explorado bastante o fato de que os ocupantes pagavam "alugueis" de 250 a 500 reais para o movimento, reforçando o discurso de criminalização da ocupação.

Entre os arquitetos e urbanistas, secundados por intelectuais ou ativistas interessados na questão urbana, estabeleceu-se uma curiosa (inesperada?) polarização.

Aqueles que enfatizaram a perda simbólica e material de um edifício emblemático foram acusados de insensibilidade frente ao drama das 146 famílias que lá perderam o pouco que tinham, quando não a própria vida. 
Outros, que focaram o drama dos moradores relevando as especificidades e o valor histórico do edifício, chegaram a ser chamados, em manifestações nas redes sociais de "os arquitetos da política". O que, considerado o apreço social pela política no Brasil atual, não parece propriamente um elogio.

Não faltaram também as críticas àqueles que cederam à tentação de usar um recurso do facebook para avisar amigos e parentes que "estavam seguros".

Nessa algaravia potenciada pelo laissez parler das redes sociais é necessário reconhecer que algumas vozes chamaram a atenção para a irracionalidade dessa oposição, destacando que os processos de esvaziamento e decadência de áreas centrais e a crise de moradia obedecem a uma mesma lógica da acumulação do capital imobiliário, expressa poeticamente na ode a São Paulo e à força da grana que ergue e destrói coisas belas, sejam edifícios ou vidas humanas. O que para alguns, eu inclusive, pareceu uma tentativa de achar uma unidade possível de discurso, também foi recebido com mal-estar.

Noutra linha de argumentação, foi preciso que um colega com militância e conhecimento de causa denunciasse o embarque no mito fácil da equivalência numérica entre déficit habitacional e número de imóveis vazios. Comparando dados de pesquisas e censos recentes ele chamou a atenção para o fato de que imóveis vazios não estão necessariamente onde se concentram as famílias sem moradia.

Esse lembrete deveria nos levar a perguntar se a evidentemente necessária adequação de imóveis vazios nas áreas centrais de nossas grandes e médias cidades para moradia não é muito mais importante para a preservação das próprias áreas centrais do que para o enfrentamento do déficit habitacional em si. Assim como a refletir sobre os riscos de consequente gentrificação, a exemplo de outras cidades que "requalificaram" a moradia em suas áreas centrais.

Certamente devemos continuar insistindo na necessidade de aplicar os instrumentos previstos no chamado Estatuto das Cidades (a lei 10257/2001), em particular o IPTU progressivo e o direito de preempção. Mas não há como negar que, nesta oportunidade, como categoria, arquitetos e urbanistas não conseguiram ocupar o espaço social do debate de maneira clara e consistente com a sua auto atribuída responsabilidade social.

O que também leva a perguntar se o debate arquitetônico, cuja precariedade se revelou nas redes sociais, está melhor nas nossas escolas.

Pela dinâmica do noticiário, seja na grande mídia ou mais ainda nas redes, a probabilidade de que este drama tratado como tragédia dure nos top trends é de mínima a inexistente.

E a questão que fica é o que poderíamos, num âmbito mais restrito das escolas e do debate profissional, reter, aprender e melhorar. Nas nossas leituras, no nosso discurso profissional colocado na esfera pública e no processo de formação dos novos profissionais.

Em outras palavras a questão é, se neste como em tantos outros temas, não estamos esquecendo de fazer as perguntas pertinentes e cedendo à tentação das respostas 
fáceis. Em linguagem de redes sociais, não estaremos também nós cedendo à dinâmica da lacração em detrimento da reflexão?

O incêndio do Joelma, quarenta e quatro anos antes, de maior repercussão tanto pelo fato de ser um edifício recém-inaugurado quanto pelas cerca de 180 vítimas fatais, teve consequências tanto na responsabilização civil e criminal dos responsáveis pelo edifício quanto na alteração da legislação municipal relativa à prevenção de incêndios. Quanto ao Paes de Almeida, o que extrairemos socialmente de um desastre? Que aprendizados? Que ações, além da obviamente necessária solidariedade às vítimas?

Dados da Prefeitura Municipal indicam a existência de cerca de 70 edifícios ocupados na cidade de São Paulo abrigando ao redor de 4000 famílias. Algumas dessas ocupações conseguiram regularizar a situação do imóvel e apresentam boas condições de funcionamento. Outras nem tanto. Técnicos da Secretaria Municipal de Habitação afirmam que pelo menos quinze delas apresentam situação de risco iminente.

A escassos vinte dias do acontecimento já rareiam as manifestações nas redes sociais e a grande mídia parece ter espremido toda a matéria prima cor de sangue para o sensacionalismo barato que, aparentemente, vende bem.

Os "arquitetos da política" e os "arquitetos da arquitetura" conseguirão estabelecer uma plataforma de reflexão comum ou continuaremos a lamentar o descaso social e das autoridades tanto com o destino da população pobre de nossas belindias urbanas como com o valor cultural de edifícios que, parece, só nós reconhecemos? 